\title{
Development of caries adjacent to composite restorations after exposure to dentifrices with different fluoride concentrations
}

\author{
Desenvolvimento de cárie adjacente a restaurações de resina composta após exposição \\ à dentifrícios fluoretados de diferentes concentrações
}

\author{
Dayse Andrade ROMÃOa , Guilherme José Pimentel Lopes de OLIVEIRA', \\ José Ivo Limeira dos REISc ${ }^{c}$ Lucineide de Melo SANTOS ${ }^{c *}$
}

\author{
${ }^{a}$ Faculdade de Odontologia, UNICAMP - Universidade Estadual de Campinas, Piracicaba, SP, Brasil \\ ${ }^{\mathrm{b}}$ Faculdade de Odontologia, UNESP - Univ Estadual Paulista, Araraquara, SP, Brasil \\ 'Faculdade de Odontologia, UFAL - Universidade Federal de Alagoas, Maceió, AL, Brasil
}

\begin{abstract}
Resumo
Objetivo: Avaliar o desenvolvimento de cárie recorrente após exposição à dentifrícios fluoretados de diferentes concentrações. Material e método: 48 amostras de incisivos bovinos com área exposta de $4 \mathrm{x} 4 \mathrm{~mm}^{2}$ foram submetidos a ciclagens de $\mathrm{pH}$ por 7 dias e em seguida foram preparadas cavidades com $2 \mathrm{~mm}$ de profundidade que restauradas com resina microhibrida. Posteriormente, as amostras foram submetidas à ciclagem térmica (350 ciclos) e confeccionados blocos de esmalte distribuídos aleatoriamente em 4 grupos de tratamento $(\mathrm{n}=12)$ : Grupo A- dentifrício sem flúor (controle negativo); Grupo B- dentifrício 500 ppm; Grupo C- dentifrício 750 ppm; Grupo D- dentifrício 1100 ppm (controle positivo). As amostras foram tratadas com soluções de cada dentifrício $(9,6 \mathrm{ml}$ água/1,6 g de dentifrício) por 60 segundos e em seguida imersas em soluções desmineralizante $(3 \mathrm{~h})$ e remineralizante $(2 \mathrm{~h}), 3$ vezes ao dia, permanecendo posteriormente 18 horas em solução remineralizante. Em seguida, os blocos foram seccionados para análise da profundidade da lesão de cárie em microscopia de luz polarizada. Os dados foram submetidos ao teste paramétrico de Anova complementado pelo teste de Tukey com nível de confiança de 95\%. Resultado: Uma menor profundidade da lesão foi verificada no grupo tratado com dentifrício de 1100 ppm F, porém não houve diferença significativa entre os dentifrícios de 500 e 750 ppm F. Conclusão: A utilização de dentifrício fluoretado (1100 ppm) interfere na redução do desenvolvimento de lesões de cárie adjacentes a restaurações.
\end{abstract}

Descritores: Cárie dentária; dentifrícios; materiais dentários.

\begin{abstract}
Objective: To evaluate the development of recurrent caries after exposure to fluoride dentifrices with different concentrations. Material and method: 48 samples of bovine incisors $\left(4 \mathrm{x} 4 \mathrm{~mm}^{2}\right)$ were exposed to $\mathrm{pH}$ cycling for 7 days before the preparation of the cavities ( $2 \mathrm{~mm}$ deep). The samples were restored with a microhybrid resin composite. Then, the samples were exposed to thermal cycling (350 cycles) and they were randomly allocated into 4 treatment groups $(\mathrm{n}=12)$ : Group A - non-fluoridated dentifrice (negative control); Group B - 500 ppm dentifrice; Group C - 750 ppm dentifrice; group D - 1100 ppm dentifrice (positive control). The samples were treated with solutions of each dentifrice $(9.6 \mathrm{ml}$ water/1.6 g dentifrice) for 60 seconds and then were immersed in demineralizing $(3 \mathrm{~h})$ and remineralizing $(2 \mathrm{~h})$ solutions 3 times a day. Next, the samples were immersed in a remineralizing solution for 18 hours. Then, the blocks were sectioned for examination of the length of the outer caries lesion, using polarized light microscopy. The ANOVA parametric test complemented by the Tukey test with a confidence level of 95\%, were used in the statistical analysis. Result: A smaller lesion length was observed in the group treated with the fluoride concentration of $1100 \mathrm{ppm} \mathrm{F}$, but there were no differences between toothpastes with fluoride concentrations of 500 and $750 \mathrm{ppm}$ F. Conclusion: The use of fluoride dentifrices (1100 ppm) reduces the development of caries adjacent to dental restorations.
\end{abstract}

Descriptors: Dental caries; dentifrices; dental materials. 


\section{INTRODUCTION}

The use of fluoride is considered one of the most effective methods for the control of dental caries because it interferes with the dynamics of the carious process, acting to inhibit demineralization and strengthening remineralization ${ }^{1,2}$. One of its most common uses is in fluoride dentifrice, considered one of the products with the greatest cariostatic effect when used daily ${ }^{3,4}$. For this reason, the fluoride must be chemically free in its formulation, ensuring its bio-availability in the oral cavity during and after brushing.

However, the excessive use of fluoride may cause toxic reactions such as dental fluorosis, which is considered a systemic effect secondary to the chronic, total ingestion and absorption of fluoride and which depends on the amount of fluoride in the dentifrice, the length of exposure, the stage of tooth development, the moment of exposure and variations in individual susceptibility ${ }^{6}$. Therefore, some alternatives have been implemented to reduce the risk of fluorosis such as reducing the amount of the dentifrice applied to the tooth brush, in order to reduce its consumption ${ }^{7}$, and the manufacture of dentifrices with low concentrations of fluoride ${ }^{8,9}$.

On the other hand, the fluoride does not interfere with the factors responsible for the caries (diet and biofilm) or with the behavior of the individual ${ }^{2}$. In patients with previous experience of caries and who have restorations, if the carie is not treated, a lesion adjacent to the restoration, called recurrent caries, could occur $^{2,10}$. This type of lesion presents a problem with high personal and social cost and is one of the main reasons for the replacement of restorations ${ }^{10}$.

The presence of fluoride, supplied mainly by the use of dentifrices, may interfere with the formation of new caries due to the maintenance of its concentration in the saliva and biofilme ${ }^{4}$. Dentifrices with low concentrations of fluoride have also been suggested for children, but the efficacy of these products in the formation of recurrent caries has received little attention in spite of the data, from SB Brasil 2010, demonstrating that children up to 5 years of age present $13.6 \%$ of the dental fillings and by 12 years of age the number of filled teeth increases to $35.3 \%{ }^{11}$.

For this reason, the purpose of this study was to evaluate the development of caries adjacent to composite resin restorations after exposure to fluoridated dentifrices of different concentrations.

\section{MATERIAL AND METHOD}

\section{Preparation of the Specimens}

Forty-eight bovine incisors were selected for this study. They were cleaned with periodontal curettes, received prophylaxis with pumice and water and were examined using a stereoscopic magnifying glass in order to discard those with possible stains, cracks or other defects that would interfere with the conduct of this study. Following selection, the teeth were stored in a $0.1 \%$ thymol solution at $4{ }^{\circ} \mathrm{C}$ for 30 days. The coronal portion was sectioned transversally using a 7020 double-faced diamond disc
(KG Sorensen), approximately $4 \mathrm{~mm}$ above the cementoenamel junction.

Afterward, the samples were submitted to $\mathrm{pH}$ cycling ${ }^{12,13}$ in demineralizing $(2.0 \mathrm{mM} / \mathrm{mL}$ of calcium and phosphate in a $75 \mathrm{mM} / \mathrm{mL}$ acetate buffer, with $\mathrm{pH}=4.3)$ and remineralizing ( $1.5 \mathrm{mM} / \mathrm{L}$ of calcium, $0.9 \mathrm{mM} / \mathrm{L}$ of phosphate, $150 \mathrm{mM} / \mathrm{mL}$ of potassium chloride in a $20 \mathrm{mM} / \mathrm{mL}$ cacodylate buffer, with $\mathrm{pH}=$ 7.0) solutions, in order to create artificial caries. The samples were immersed ( $5 \mathrm{ml} / \mathrm{sample}$ ) in the demineralizing solution (37 ${ }^{\circ} \mathrm{C}$ ) for three hours, and then placed in another container with the remineralizing solution $\left(37^{\circ} \mathrm{C}\right)$ for 21 hours. This procedure was repeated for a total of $5 \mathrm{pH}$ cycles over 7 days. Both before and after immersion in the solutions, the samples were washed with deionized water and dried with absorbent paper. The demineralizing and remineralizing solutions were changed daily to prevent their saturation, as well as accumulation of dissolved enamel products.

Following these procedures, cavities were prepared in the middle third of the vestibular face of the incisors using diamond burs (KG Sorensen 1014, Barueri, São Paulo, Brazil) mounted on a high-speed turbine (Dabi Atlante, Ribeirão Preto, São Paulo, Brazil) with air/water cooling. A silicone pointer (Ângelus, Londrina, Paraná, Brazil) was placed $2 \mathrm{~mm}$ from the active end point of the bur, standardizing the depth of the cavities. Upon completing the preparation, the cylindrical cavities measured $2 \times 2 \times 2 \mathrm{~mm}$. Following the preparation of the cavities, the teeth were sectioned to obtain blocks measuring approximately $6 \times 6 \times 4 \mathrm{~mm}$. To gain parallelism on the lower faces of the blocks, sheets of water sandpaper in decreasing order of granulation (220, 400 and 600) attached to a electric polisher (AROTEC, São Paulo, Brazil) were used. Then, the blocks were cleaned using pumice stone with water and ultrasound.

The specimens were restored according to manufacturer's instructions using a Filtek Z250 (3M/ESPE, Sumaré, São Paulo, Brazil) microhybrid resin composite with A2 color, Adper Single Bond 2 (3M/ESPE, Sumaré, São Paulo, Brazil) adhesive system and Super Etch (SDI, São Paulo, Brazil) 37\% phosphoric acid in a single application, and light cured for 60 seconds using an LED curing light (Gnatus, Ribeirão Preto, SP, Brazil). Following preparation of the restorations, the specimens were stored in an incubator at $37{ }^{\circ} \mathrm{C}$ for 24 hours to permit the complete polymerization of the material. Then, polishing and finishing of the restorations was done using Sof-Lex (3M ESPE, Sumaré, São Paulo, Brazil) discs. Immediately thereafter, a layer of nail polish (Risquè, Niasi, SP, Brazil) was applied to the entire specimen, leaving only the restoration exposed. Afterward, the specimens were subjected to thermal cycling in baths of hot $\left(55^{\circ} \mathrm{C}\right)$ and cold $\left(5^{\circ} \mathrm{C}\right)$ water, for a total of 350 cycles (Cycling Machine), Nova Ética, São Carlos, $\mathrm{SP}$, Brazil) to simulate the range of temperature that occurs in the oral cavity due to the ingestion of foods of different temperatures.

\section{Treatment of the Specimens}

Following preparation of the samples, the specimens were randomly distributed (Excel Microsoft Office) among 4 treatment groups $(n=12)$. Table 1 shows the composition and amount of 
Table 1. Information about the dentifrices analyzed

\begin{tabular}{ccccc}
\hline Groups & Concentration F (ppm) & Fluoride Agent & Commercial Name & Manufacturer \\
\hline A & No fluoride & $\mathrm{NaF}$ & Cocoricó & Bitufo/Brasil \\
B & $500 \mathrm{ppm}$ & $\mathrm{NaF}$ & Barney & Colgate/Brasil \\
C & $750 \mathrm{ppm}$ & $\mathrm{NaF}$ & Ben 10 & Bitufo/Brasil \\
$\mathrm{D}$ & $1100 \mathrm{ppm}$ & $\mathrm{NaF}$ & Tandy & Kolynos/Brasil \\
\hline
\end{tabular}

dentifrice used by each group. All groups were treated for a period of 7 days ${ }^{14}$, subjected to the specific dentifrice for 60 seconds 3 times a day and immersed in a demineralizing solution $(2.0 \mathrm{mM} / \mathrm{mL}$ of calcium and phosphate in a $75 \mathrm{mM} / \mathrm{mL}$ acetate buffer with $\mathrm{pH}=4.3$ ) for 3 hours and in a remineralizing solution $(1.5 \mathrm{mM} / \mathrm{L}$ of calcium, $0.9 \mathrm{mM} / \mathrm{L}$ of phosphate, $150 \mathrm{mM} / \mathrm{mL}$ of potassium chloride in a $20 \mathrm{mM} / \mathrm{mL}$ cacodylate buffer with $\mathrm{pH}=7.0)^{12}$ two times a day with a two-hour interval between them. The samples remained in the remineralizing solution overnight. Both before and after immersion in the solutions, the samples were washed with deionized water and dried with absorbent paper.

\section{Analysis with Polarized Light}

After the treatment period, the samples were analyzed using polarized light microscopy. For this analysis, the samples were sectioned using a 7020 double faced diamond disc (KG Sorensen, São Paulo, Brazil) attached to a cutting machine and then smoothed using 300 and $600 \mu \mathrm{m}$ granulated water sandpaper, producing sections of 100 to $150 \mu \mathrm{m}$. The sections were fixed with slides and cover slips, and soaked in water for 48 hours. After this period, they were observed under polarized light microscopy (Quimis-Motic BA 300 with polarizing filter SW0199UH) (Diadema, SP, Brazil) with an attached camera. The images were captured using lenses of 40X magnification, and then transferred to a computer monitor and the depths of the caries in the enamel were measured using the Bel Microlmage Analyser (Monza, MB, Italy) software. The depth of the external carie in micrometers is considered to be the greatest distance between the external surface of the enamel and internal edge of the carie.

\section{Statistical Analysis}

The data from this study were numeric and, for this reason, the Shapiro-Wilk test was used to determine whether the data were distributed according to the central distribution theorem. The data were verified to be normally distributed ( $p>0.05)$ and, for this reason, the ANOVA parametric test, complemented by the Tukey test, was used for inferential analysis of the data. All tests were conducted at the $95 \%$ confidence level $(\mathrm{p}<0.05)$. The Graphpad Prism 6 (San Diego, CA, USA) software was used to conduct the statistical analyses.

\section{RESULT}

Table 2 shows the mean and the standard deviation of the measurements of the depths of the caries in the enamel, according
Table 2. Mean and standard deviation of the depth of the external carie in the enamel $(\mu \mathrm{m})$ in the different groups

\begin{tabular}{cc}
\hline Groups & $\begin{array}{c}\text { MEAN } \pm \text { STANDARD DE- } \\
\text { VIATION }\end{array}$ \\
\hline Group A (no fluoride) & $147.44 \pm 23.88 \mathrm{a}$ \\
Group B (500 ppm) & $116.69 \pm 19.77 \mathrm{~b}$ \\
Group C (750 ppm) & $117.83 \pm 18.68 \mathrm{~b}$ \\
Group D (1100 ppm) & $77.31 \pm 14.58 \mathrm{c}$ \\
\hline
\end{tabular}

Comparison among the groups in relation to the depths of the external caries $(\mu \mathrm{m})$. Different letters indicate statistical difference between groups $(\mathrm{p}<0.05)$. ANOVA complemented by Tukey test.

to treatment group. The results show the values of the depths of the caries in the enamel of the dental blocks after exposure to the dentifrices, fluoridated in different concentrations. In the comparisons between the different treatments, the group exposed to the non-fluoridated solution (Group A) showed the greatest depth of caries $(\mu \mathrm{m})$ in the enamel $(\mathrm{p}<0.05)$, whereas the group treated with the $1100 \mathrm{ppm} F$ dentifrice (Group D) showed the smallest carie in the dental substrate $(\mathrm{p}<0.05)$. Groups B and C, exposed to 750 and 500 ppm F dentifrices, respectively, showed similar carie depths in the enamel $(\mathrm{p}>0.05)$ and had statistical values less than Group A $(\mathrm{p}<0.05)$ and greater than Group D $(\mathrm{p}<0.05)$.

\section{DISCUSSION}

The literature shows that fluoridated dentifrice has a significant effect on the reduction of caries $^{2,3}$; however, its unsupervised use by small children may result in undesired ingestion of the fluoride. This has encouraged the development of dentifrices with low fluoride concentrations and of techniques for reducing their consumption, as alternatives for reducing the risk of dental fluorosis ${ }^{7,8,14,15}$. Additionally, it is possible to see that, in Brazil, there was a small increase in the number of children up to 12 years old who had experience with caries requiring restorative treatment ${ }^{11}$; and, that the use of composites in children has increased ${ }^{16}$.

The results of the present study show less depth of caries in the enamel of the groups treated with fluoridated dentifrice when compared to the control group. These data are statistically significant and, although it may be observed that caries were found in all groups, these results show the importance of fluoride, even in small concentrations, in the reduction of caries. The importance of dentifrices containing fluoride in the reduction 
of caries is incontrovertible, since the daily use of this product provides a concentration of fluoride sufficient to maintain levels that contribute actively to the processes of reduction of demineralization and activation of remineralization ${ }^{2}$. This is mainly in children that have had experience with caries and who continue to have increased risk of developing this disease ${ }^{10}$.

One of the materials of choice for restorations in primary teeth is the composite; however, when these restorations are not properly prepared, in terms of polishing and finishing, they become areas susceptible to the accumulation of biofilm ${ }^{10,16,17}$. If the caries in the child have not been controlled, it remains susceptible to the development of new caries near the restoration. One of the ways of reducing the development of caries is to offer a dentifrice that will supply the fluoride ion and that will also help in the disorganization of the biofilm through brushing ${ }^{4}$. However, the present study has some limitations that do not address this aspect, as there was no formation of biofilm, only exposure to cycling. Bovine teeth were used as the evaluated substrate and evaluation of the carie was done using only one technique. Nevertheless, the polarized light microscopy used in this study is considered an effective imaging technique for the evaluation of demineralization of the substrate, permitting analysis of the depth of the carie.

Regarding fluoridated dentifrices, it was possible to verify that the $1100 \mathrm{pm}$ F concentration presented the best anticarie effect, having the least depth of external carie adjacent to the composite $(77.31 \mu \mathrm{m})$. These results, from the group with the greater concentration of fluoride, differed statistically from the other groups, confirming its better performance in the mechanism of carie development. Thus, these results provide scientific evidence to corroborate the efficacy of dentifrices having high concentration, because a dentifrice must have at least 1000 ppm of fluoride in soluble form in order to have an anticarie effect ${ }^{18}$. Concentrations less than 1000 ppm F are not capable of inhibiting the development of caries in highly challenging cariogenic situations ${ }^{19}$ or in the presence of active caries ${ }^{20}$. These processes are constantly active mainly in children with increased risk of caries.

One study that compared the effect of different amounts of dentifrice with different concentrations verified that there was no statistically significant difference in the depths of the caries in primary teeth, and did not compromise the efficacy of its mechanism of action ${ }^{21}$. Another study, which also used primary teeth, verified that the reduction in the amount of dentifrice must be done with caution as it may compromise the cariostatic effect of the product. However, only non-fluoridated dentifrices and dentifrices having 500 ppm F were evaluated ${ }^{14}$. Presently, the results of the concentrations evaluated in this study confirm the importance of using a dentifrice having a high [fluoride] concentration even in a reduced amount $(1.6 \mathrm{~g})$, about the size of half of a pea ${ }^{14}$, when compared to low concentrations, for reducing the formation of new caries. It is worth noting that the comparison between different amounts of dentrifice, as well as different types of dental substrate, were not evaluated in the present study. This suggests the need for new studies.

Regarding the depth of caries adjacent to the composite, evaluated in the groups treated with low F concentrations (500 and $750 \mathrm{ppm}$ ), it may be claimed that there was no statistically significant difference between them. This suggests that the greater concentration of fluoride in the $750 \mathrm{ppm} F$ dentifrice does not provide greater protection in relation to the $500 \mathrm{ppm}$ F. Therefore, both dentifrices present a limited anticarie effect in relation to the 1100 ppm dentifrice. The lack of literature evaluating dentifrices containing $750 \mathrm{ppm} \mathrm{F}$ on the formation of caries adjacent to composite restorations should be noted. Nevertheless, studies do report that low concentration dentifrices are less effective in inhibiting caries ${ }^{18,22}$.

Therefore, the results suggest the necessity of using dentifrices with concentrations of at least $1000 \mathrm{ppm} F$ in order to reduce dental demineralization; and, there is no necessity of using large amounts of dentifrice which could increase the ingestion of fluoride by children ${ }^{4}$, thus permitting them to offer the maximum protective effect and reduce the risk of fluorosis. However, this demands the application of educational and supervisory measures by parents, the evaluation of the individual characteristics of each patient, evaluation of the risk and activity of caries and the use of other sources of fluoride in order to reduce the incidence of recurrent caries.

\section{CONCLUSION}

Given the above, and the limitations of the present study, the results suggest that the use of fluoridated dentifrice may interfere with the reduction of the development of caries adjacent to restorations and that dentifrices with concentrations of $1100 \mathrm{ppm}$ F present greater anticarie effect.

\section{REFERENCES}

1. Ten Cate JM. In vitro studies on the effects of fluoride on de- and remineralization. J Dent Res. 1990 February;69(Spec No):614-9, discussion 634-6. PMid:2179322.

2. Cury JA, Tenuta LM. Enamel remineralization: controlling the caries disease or treating early caries lesions? Braz Oral Res. 2009; 23(Suppl 1):23-30. http://dx.doi.org/10.1590/S1806-83242009000500005. PMid:19838555

3. Toda S, Featherstone JD. Effects of fluoride dentifrices on enamel lesion formation. J Dent Res. 2008 March;87(3):224-7. http://dx.doi. org/10.1177/154405910808700303. PMid:18296604

4. Tenuta LM, Cury JA. Fluoride: its role in dentistry. Braz Oral Res. 2010; 24(Suppl 1):9-17. http://dx.doi.org/10.1590/S180683242010000500003. PMid:20857070

5. Cury JA, Oliveira MJ, Martins CC, Tenuta LMA, Paiva SM. Available fluoride in toothpastes used by Brazilian children. Braz Dent J. 2010; 21(5):396-400. http://dx.doi.org/10.1590/S0103-64402010000500003. PMid:21180793 
6. de Almeida BS, da Silva Cardoso VE, Buzalaf MA. Fluoride ingestion from toothpaste and diet in 1- to 3-year-old Brazilian children. Community Dent Oral Epidemiol. 2007 February;35(1):53-63. http://dx.doi.org/10.1111/j.1600-0528.2007.00328.x. PMid:17244138

7. DenBesten P, Ko HS. Fluoride levels in whole saliva of preschool children after brushing with $0.25 \mathrm{~g}$ (pea-sized) as compared to $1.0 \mathrm{~g}$ (fullbrush) of a fluoride dentifrice. Pediatr Dent. 1996 July-August;18(4):277-80. PMid:8857654.

8. Moraes SM, Pessan JP, Ramires I, Buzalaf MA. Fluoride intake from regular and low fluoride dentifrices by 2-3-year-old children: influence of the dentifrice flavor. Braz Oral Res. 2007 July-September;21(3):234-40. http://dx.doi.org/10.1590/S1806-83242007000300008. PMid:17710289

9. Queiroz CS, Hara AT, Paes Leme AF, Cury JA. pH-cycling models to evaluate the effect of low fluoride dentifrice on enamel de- and remineralization. Braz Dent J. 2008; 19(1):21-7. http://dx.doi.org/10.1590/S0103-64402008000100004. PMid:18438555

10. Lima FG, Romano AR, Correa MB, Demarco FF. Influence of microleakage, surface roughness and biofilm control on secondary caries formation around composite resin restorations: an in situ evaluation. J Appl Oral Sci. 2009 January-February;17(1):61-5. http://dx.doi. org/10.1590/S1678-77572009000100012. PMid:19148408

11. Brasil. Ministério da Saúde. Projeto SB Brasil 2010: Pesquisa nacional de saúde bucal: resultados principais. Brasília: Ministério da Saúde; 2011.

12. Featherstone JD, Holmen L, Thylstrup A, Fredebo L, Shariati M. Chemical and histological changes during development of artificial caries. Caries Res. 1985; 19(1):1-10. http://dx.doi.org/10.1159/000260824. PMid:3856481

13. Chedid SJ, Cury JA. Effect of $0.02 \% \mathrm{NaF}$ solution on enamel demineralization and fluoride uptake by deciduous teeth in vitro. Braz Oral Res. 2004 January-March;18(1):18-22. http://dx.doi.org/10.1590/S1806-83242004000100004. PMid:15273781

14. Itthagarun A, Thaveesangpanich P, King NM, Tay FR, Wefel JS. Effects of different amounts of a low fluoride toothpaste on primary enamel lesion progression: a preliminary study using in vitro pH-cycling system. Eur Arch Paediatr Dent. 2007 March;8(1):69-73. http://dx.doi. org/10.1007/BF03262573. PMid:17394894

15. Hellwig E, Altenburger M, Attin T, Lussi A, Buchalla W. Remineralization of initial carious lesions in deciduous enamel after application of dentifrices of different fluoride concentrations. Clin Oral Investig. 2010 June;14(3):265-9.; published online June 2, 2009. http://dx.doi. org/10.1007/s00784-009-0290-4. PMid:19488796

16. Bücher K, Tautz A, Hickel R, Kühnisch J. Longevity of composite restorations in patients with early childhood caries (ECC). Clin Oral Investig. 2014 April;18(3):775-82.; published online July 20, 2013. http://dx.doi.org/10.1007/s00784-013-1043-y. PMid:23873324

17. Reis AF, Giannini M, Lovadino JR, dos Santos Dias CT. The effect of six polishing systems on the surface roughness of two packable resinbased composites. Am J Dent. 2002 June;15(3):193-7. PMid:12469758.

18. Walsh T, Worthington HV, Glenny AM, Appelbe P, Marinho VC, Shi X. Fluoride toothpastes of different concentrations for preventing dental caries in children and adolescents. Cochrane Database Syst Rev. 2010; (1):CD007868. http://dx.doi.org/10.1002/14651858. CD007868.pub2. PMid:20091655.

19. Cury JA, do Amaral RC, Tenuta LM, Del Bel Cury AA, Tabchoury CP. Low-fluoride toothpaste and deciduous enamel demineralization under biofilm accumulation and sucrose exposure. Eur J Oral Sci. 2010 August;118(4):370-5. http://dx.doi.org/10.1111/j.1600-0722.2010.00745.x. PMid:20662910

20. Lima TJ, Ribeiro CC, Tenuta LM, Cury JA. Low-fluoride dentifrice and caries lesion control in children with different caries experience: a randomized clinical trial. Caries Res. 2008; 42(1):46-50.; published online November 27, 2007. http://dx.doi.org/10.1159/000111749. PMid:18042987

21. Rirattanapong P, Smutkeeree A, Surarit R, Saendsirinavin C, Kunanantsak V. Effects of fluoride dentifrice on remineralization of demineralized primary enamel. Southeast Asian J Trop Med Public Health. 2010 January;41(1):243-9. PMid:20578505.

22. Nobre-dos-Santos M, Rodrigues LK, Del-Bel-Cury AA, Cury JA. In situ effect of a dentifrice with low fluoride concentration and low $\mathrm{pH}$ on enamel remineralization and fluoride uptake. J Oral Sci. 2007 June;49(2):147-54. http://dx.doi.org/10.2334/josnusd.49.147. PMid:17634728

\section{CONFLICTS OF INTERESTS}

The authors declare no conflicts of interest.

\section{${ }^{*}$ CORRESPONDING AUTHOR}

Lucineide de Melo Santos, Departamento de Dentística, FOUFAL - Faculdade de Odontologia da Universidade Federal de Alagoas, Av. Lourival Melo Mota, s/n, Tabuleiro do Martins, 57072-970 Maceió - AL, Brasil, e-mail: jilreis@uol.com.br 